\title{
Urinary Incontinence in Women Aged 25-64 in Turkey: A Cross-Sectional Research
}

\section{Türkiye'de 25-64 Yaş Arası Kadınlarda İdrar Kaçırma: Kesitsel Bir Araștırma}

\author{
Fatih $\ddot{z}_{z c a n}{ }^{* 1}$, Cüneyd $\ddot{O ̈ z k u ̈ r k c ̧ u ̈ g i l}^{2}$, Nilay Etiler ${ }^{3}$
}

\begin{abstract}
Objective: The study aimed to determine the prevalence of urinary incontinence (UI) in a representative sample of women living in Turkey at the national level and to investigate predisposing factors. Methods: A cross-sectional study was conducted nationwide on women aged 25-64. Women were selected from Family Physicians' lists using random sampling. For data collection, a valid Turkish questionnaire; the international incontinence questionnaire - short form (ICIQ-SF) was used. An ICIQ-SF questionnaire is a form of inquiry that assesses the presence and severity of urinary incontinence and predisposing factors were Results: A total of 1,179 participants took part. The median age was $43 \pm 10.8$ years. "Do you always leak urine?" the prevalence of UI was $43.9 \%$ in the answer to the question. Furthermore, the UI prevalence was $47.4 \%(559 / 1179)$ according to the ICIQ-SF survey. The prevalence of UI did not differ between regions, but the difference between increased vaginal births $(\geq 3)$, advanced age, and low educational status was significant $(p<0.05)$. Conclusion: The high rate of UI among women in Turkey indicates an important women's health problem that can be prevented by some studies. We believe it is important that this is taken into account in national preventive women's health programs. We recommend that the ICIQ-SF query form be included in national preventive women's health programs by taking routine practice as a screening tool to detect urinary incontinence in adult women.
\end{abstract}

Key words: Urinary incontinence, ICIQ-SF, cross-sectional research, population-based research

\section{ÖZET}

Amaç: Çalışmanın amacı, Türkiye'de yaşayan kadınların ulusal düzeyde temsili örnekleminde, üriner inkontinans (ÜI) prevalansını saptamak ve predispozan faktörleri araştırmaktı. Yöntem: Yaşları 25-64 olan kadınlar üzerinde ülke çapında kesitsel bir çalışma yapıldı. Kadınlar, aile hekimliği listelerinden rastgele örnekleme kullanılarak seçildi. Veri toplama için geçerliliği onaylanmış Türkçe bir anket; Uluslararası İnkontinans Anketi - kısa formu (ICIQ-SF) kullanıldı. ICIQ-SF anketi, idrar kaçırmanın varlığını ve ciddiyetini değerlendiren bir sorgu formu olup predispozan faktörler incelendi. Bulgular: Toplam

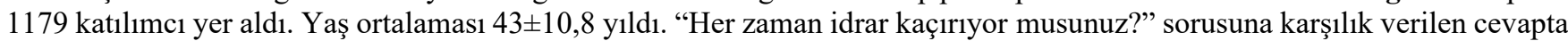
Üİ prevalans1 \%43,9 bulundu. Ayrıca, ICIQ-SF anketine göre UI prevalans1 \%47,4 (559/1179) idi. Üİ prevalansı bölgeler arasında farklılık göstermedi ancak artan vajinal doğum sayısı $(\geq 3)$, ileri yaş ve düşük eğitim düzeyi arasındaki fark anlamlı idi $(\mathrm{p}<0.05)$. Sonuç: Türkiye'de kadınlar arasında Üİ oranının yüksek oluşu, bazı çalışmalarla önlenebilecek önemli bir kadın sağlı̆̆ sorununa işaret etmektedir. Bu durumun ulusal koruyucu kadın sağlığı programlarında dikkate alınmasının önemli olduğuna inanıoruz. ICIQ-SF sorgu formunun erişkin kadınlarda idrar kaçırma sorununun saptanması için bir tarama aracı olarak rutin uygulamaya alınarak ulusal koruyucu kadın sağlı̆̆ı programlarında yer almasını öneriyoruz.

Anahtar kelimeler: İdrar kaçırma, ICIQ-SF, kesitsel araştırma, nüfus tabanlı araştırma

Received / Geliş tarihi: 22.06.2021, Accepted / Kabul tarihi: 27.10.2021

${ }^{1}$ Manisa Celal Bayar University Faculty of Medicine, Department of Family Medicine, MANISA (ORCID: 0000-0001-9380-5227)

${ }^{2}$ Kocaeli University Faculty of Medicine, Department of Urology, KOCAELI (ORCID: 0000-0002-1021-1392)

${ }^{3}$ İstanbul Okan University Faculty of Medicine, Department of Public Health, ISTANBUL (ORCID: 0000-0001-5711-3733)

*Address for Correspondence / Yazışma Adresi: Manisa Celal Bayar University Faculty of Medicine, Department of Family Medicine, MANISA-TÜRKIYE, E-mail: fatihozcan41@gmail.com

Ozcan F, Ozkurkcugil C, Etiler N. Urinary Incontinence in Women Aged 25-64 in Turkey: A Cross-Sectional Research. TJFMPC, 2021;15(4): 853-861.

DOI: $10.21763 /$ tjfmpc.956210 


\section{INTRODUCTION}

Urinary incontinence (UI) is defined as the complaint of any involuntary leakage of urine, and the inability to control the urine is a most unpleasant and distressing problem. The prevalence of UI in women ranged from $10 \%$ to 58 percent in a study of population studies from various nations. ${ }^{1}$ There have been some Turkish regional studies concerning the prevalence rates of female UI which reported that the rates ranged from 20.9 percent to 49.7 percent. ${ }^{2-3}$

Variation in reported prevalence rates may be due to different definitions of UI and differences in studied population demographics. However, the use of the International Consultation on Incontinence Questionnaire - short form (ICQ-SF) tool, a standardized and validated questionnaire will make the results of prevalence studies more comparable. The ICIQ-SF is a four-item diseasespecific short questionnaire developed under the supervision of the International Consultation on Incontinence to assess the impact of UI on quality of life.

This study aimed to determine the prevalence of urinary incontinence (UI) in a representative sample of adult women living in Turkey at the national level and to investigate predisposing factors.

\section{METHODS}

\section{Design of research}

This cross-sectional study was conducted in a national sample representing women in the 25-64 age group in Turkey. The sample calculation method is described in detail below.

From May 2016 to March 2017, 33 Family Physicians (Primary Care Physicians) working in family health centers in 16 provinces throughout 12 regions of Turkey took part. However, in order to make data analysis easier, the data was reformatted for the country's five major areas.

\section{Population and sampling}

The decency of the study was that of adult women aged 25-64. The total number of women in this age group was $22,868,984$ in 2014 , according to the Turkish Statistical Institute's address-based Population Registration System. ${ }^{4}$ Based on a $25 \%$ default UI prevalence and a 2.5 percent margin of error, the sample size was calculated to be 1,152 people. The study's participation rate was $98.3 \%$ (n:1179), despite the fact that it was designed to involve 1200 women in order to improve the study and avoid the loss of incomplete data or samples. Participants were separated into layers initially, according to geographical regions, and then randomly sampled using two-stage selection and basic random sampling procedures. The sample size (1200 women) is given weight to each region in the first stage, with twelve regions of Turkey being given weight. ${ }^{4}$ It is distributed proportionally. As of the end of 2010, the entire population in Turkey has been included in the family medicine system by the Ministry of Health.

A list of women between the ages of 25 and 64 who volunteered to participate in the study from each center was acquired for the second phase. A random selection procedure was used to choose women from each family physician's list. He was invited to the Family Health Center by 5 people. All participants signed a written informed consent form. The women's family physicians then filled out the questionnaires in one-on-one interviews. In Turkey, physicians who work in primary health care are known as "Family Physicians."

Seniors (65 and up), pregnant women, and women with any neurogenic bladder complaint, malignancy, or indications of acute urinary infection were excluded from the study. In the supplemental table, a comparison of the population represented by the sample of this study was shown. The proportion of women who graduated from secondary school was found to be high in the study's sample.

\section{Types of equipment}

Eligible women in the study completed ICIQ-SF questionnaire forms with the supervision and assistance of Family Physicians.. The ICIQ-SF tool consists of six items, with four main items asking for a rating of UI symptoms over the past four weeks. 3, 4 and 5 . scores of substances are taken into account for the final ICIQ-SF score. 1. and 2. the items are demographic, and the final item can diagnose the type of urinary incontinence (UI) on its own. The sum of the answers ranges from 0 to 21 . The Turkish version of ICIQ-SF was approved by Çetinel. ${ }^{6}$

\section{Variables and definitions}

The dependent variable of this study was urinary incontinence as measured by the ICIQ-SF questionnaire. While ICIQ-SF scores of 1 and above identify all "incontinence", these scores are further divided into four levels of severity: 1) 1-5 = mild; 2) 6-12 = moderate; 3 ) $13-18=$ severe; and 4) 19-21 = very severe. UI types divided into stress, compression, or mixed-type incontinence were defined using the following criteria. The positive response to" leaks when coughing or sneezing "and/or" leaks when physically active/exercising "questions were defined as" stress-type UI", while" leaks before going to the toilet "was defined as" 
urge-type UI". The "Yes" response to both questions was considered "mixed". 7

The independent variables were age group, marital and educational status, work status, and types of births (number of vaginal births or caesareans, and number of live births or stillbirths).

\section{Statistical methods}

Statistical analysis Statistical Package for Social Science for Windows (SPSS), version 15.0 Software (IBM Inc., Chicago, Ill., US) was used. The ratios were compared using the chi-square test and the single sample proportion test. For multivariate analysis, a logistic regression model was used. Alpha error level was accepted at 0.05 .

\section{Ethical evaluation}

Ethical approval was obtained from Kocaeli University Clinical Research Ethics Board (dated 28/07/2015 and numbered 24/14) and written informed consent was obtained from every woman who agreed to participate in the research during the research. In addition, the study protocol was approved by the Ministry of the health of the TR (dated 30/03/2016 and 67350377/772.99).

\section{RESULTS}

Of our 1200 Female targets in the study, 1,179 $(98.3 \%)$ were included in the study. This also exceeded the fact-taking target needed to strengthen the study. The average age of the participants was $43.6 \pm 10.8$ years. The number and rate of women in each age group: $25-29$ age $\mathrm{N}=134(\% 11,4) ; 30-34$ age $n=146(\% 12,4) ; 35-39$ years $(n=190(16.1) ; 40$ 44 age $\mathrm{N}=165(\% 14,0) ; 45-49$ age $\mathrm{N}=153(\% 13,0)$; $50-54$ years, $\mathrm{N}=150(\% 12,7) ; 55-59$ years, $\mathrm{N}=140$ $(\% 11,9)$; and age 60-64 n=101 (8.6\%).

The sample is geographically distributed as follows: West $\mathrm{n}=572$ (48.5\%); Middle $\mathrm{n}=179$ (15.2\%); South $\mathrm{n}=136 \quad(11.5 \%)$; North $\mathrm{n}=100$ $(8.5 \%)$; and East $n=192(16.3 \%)$. According to the ICQ-SF survey, 559 (47.4\%) of 1,179 women had incontinence (with urinary incontinence) and 620 $(52.6 \%)$ had no urinary incontinence complaints. The intensity of UI by ICQ-SF is shown in Table 1.

Figure 1 shows the types of urinary incontinence as assessed by ICIQ-SF.

Table 1. Prevalence and severity of UI among Turkish women

\begin{tabular}{|c|c|c|c|}
\hline Severity of UI & ICI-Q score & $\mathbf{n}$ & \% \\
\hline No UI & 0 & 620 & 52.6 \\
\hline Slight & $1-5$ & 319 & 27.1 \\
\hline Moderate & $6-12$ & 174 & 14.8 \\
\hline Severe & $13-18$ & 56 & 4.7 \\
\hline Very severe & $19-21$ & 10 & 0.8 \\
\hline Total & & 119 & 100.0 \\
\hline
\end{tabular}




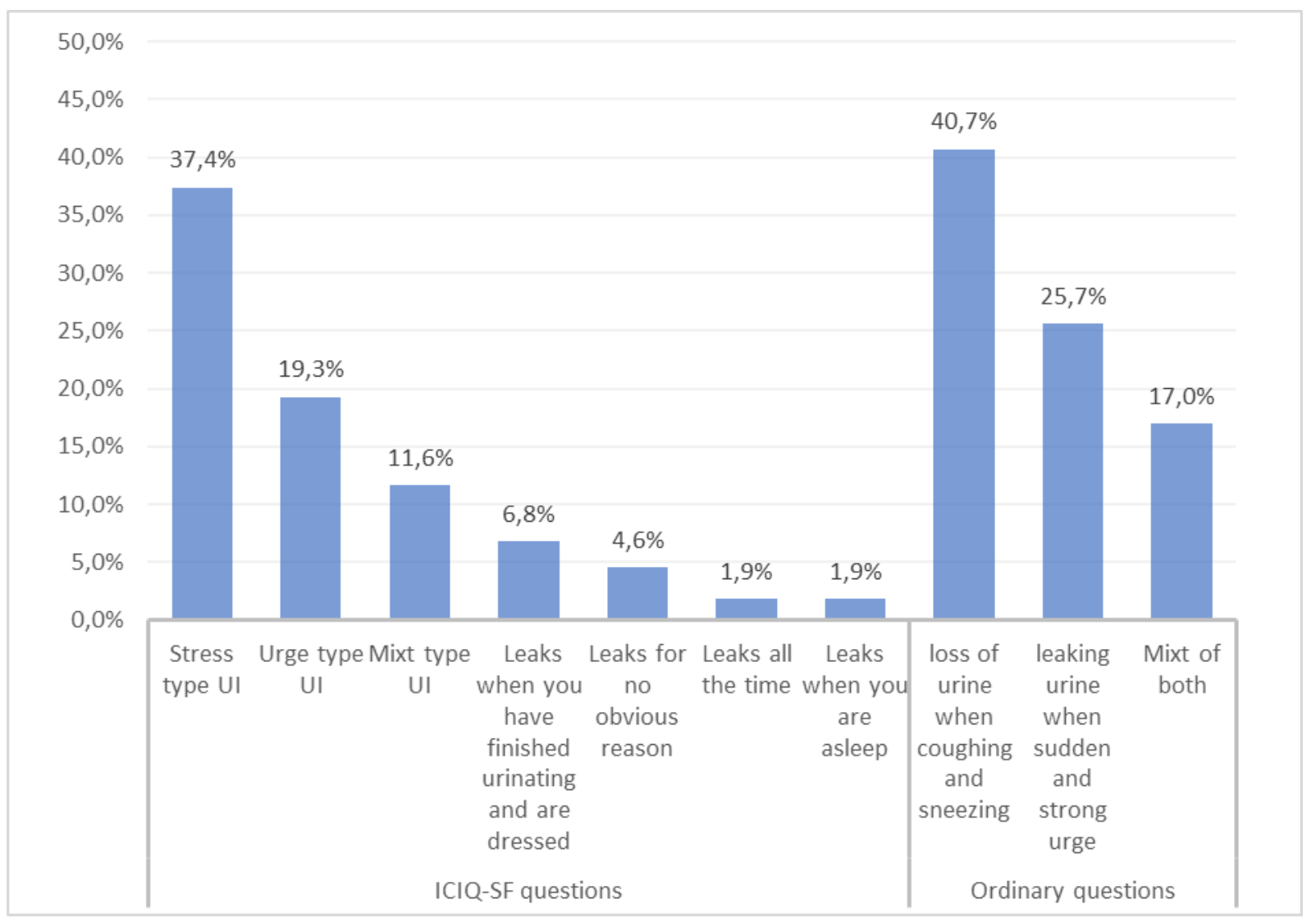

Figure 1. Both self-diagnosis rates for UI types by ICIQ and direct questions for stress type UI and urge.

In the entire sample $(\mathrm{n}=1179)$, the prevalence of stress type and urge type UI was $37.3 \%(n=440)$ and $19.3 \%(N=227)$, respectively, while the prevalence of mix UI was $11.6 \%(n=137)$.

There was no correlation between the prevalence of UI and the types of UI and geographical region, but there was some variation. The proportion of women reporting mild incontinence was consistent across all five regions. However, the Eastern region had the lowest rate of women reporting continence and also the highest rate of women reporting severe incontinence, while the northern region had the highest rate of continence reporting and, accordingly, a low rate of serious incontinence, but these differences were not significant. (Table 2).

Logistic regression analysis was performed to investigate factors related to both urinary incontinence and UI types (Table 3).
The UI variables derived from the ICIQ-SF were compared to independent variables such as age, education, and vaginal birth. The youngest age group (25-29 years) was used as a reference group for age group comparison. There were no differences between the reference age group and the next two groupings, but after the age of 40, the ORs for UI differed significantly from the reference. Both the stress and mix type UI had similar trends, but the mix type UI occurred at a slightly older age, whereas the urge UI was only significant in the 60-64 age group (OR 2.54, $\mathrm{p}=0.013$ ). Less-educated women had a significant increase in risk for all types of UIS compared to those with eight years or more of education, and women who had three or more vaginal births had a significant increase in risk compared to nulliparous women (reference group). The variables Caesarean section, marital status, and employment did not pose a risk in October (data not shown in Table 3). 
Table 2. Relation of ICIQ-SF scores and UI types by region

\begin{tabular}{|c|c|c|c|c|c|c|}
\hline & \multicolumn{3}{|c|}{ ICIQ Scores } & \multicolumn{3}{|c|}{ Self-diagnostic types of UI } \\
\hline $\begin{array}{l}\text { Geographical } \\
\text { Regions }\end{array}$ & $\begin{array}{c}\text { No IU } \\
\text { (0 score) }\end{array}$ & $\begin{array}{l}\text { Slight } \\
(1-5)\end{array}$ & $\begin{array}{c}\text { Moderate and } \\
\operatorname{high}(\geq 6)\end{array}$ & Urgency & Stress $U I$ & Mixed UI \\
\hline West & $55.4 \%$ & $26.6 \%$ & $18.0 \%$ & $18.4 \%$ & $37.8 \%$ & $10.1 \%$ \\
\hline Middle & $54.7 \%$ & $24.6 \%$ & $20.7 \%$ & $18.4 \%$ & $39.7 \%$ & $12.3 \%$ \\
\hline South & $55.1 \%$ & $26.5 \%$ & $18.4 \%$ & $19.9 \%$ & $37.5 \%$ & $14.0 \%$ \\
\hline North & $59.0 \%$ & $24.0 \%$ & $17.0 \%$ & $19.0 \%$ & $28.0 \%$ & $9.0 \%$ \\
\hline East & $47.9 \%$ & $25.4 \%$ & $26.6 \%$ & $22.4 \%$ & $38.5 \%$ & $15.1 \%$ \\
\hline$\chi^{2}$ test and $p$ value & & $\begin{array}{c}\chi^{2}: 8,365 \\
p>0.05\end{array}$ & & $\begin{array}{c}\chi^{2}: 2,628 \\
p>0.05\end{array}$ & $\begin{array}{c}\chi^{2}: 4,306 \\
p>0.05\end{array}$ & $\begin{array}{c}\chi^{2}: 4,968 \\
p>0.05\end{array}$ \\
\hline
\end{tabular}

\section{DISCUSSION}

Previously, a wide range of female UI prevalence and incidence calculations had been reported.. ${ }^{8-14}$ This difference may be due to differences in both the UI definition used and the study methodology, including the population surveyed, study design, data collection methods. The differences between subjective perception of what constitutes urinary incontinence and the ICIQ-SF survey description of UI can be attributed to the perceptions of individual participants and include those who believe UI is "normal in old age". ${ }^{15}$ In addition, women may be more embarrassed to report UI in a face-to-face interview or a computer-assisted phone call than in a written anonymous questionnaire. ${ }^{16}$ Previous studies based on localized or clinical applications to a region (mostly a city) reported that the prevalence of Dec in adult Turkish women ranged from $20 \%$ to $49.7 \%$. $2,3,17-25$

Even in similar geographic areas, reported UI rates vary significantly. Unfortunately, these studies were not population-based and had methodological limitations. Furthermore, validated questionnaires were rarely used. ${ }^{26-27}$ Our sample represented Turkish women aged 25-64 years according to characteristics such as age group, marital status and geographic location, which was similar to the national data as shown in the Additional Table. Therefore, these results are likely to represent the population of Turkey in general. "Do you lose urine at any time?" according to the subjective answer to the question, the UI was $43.9 \%$ present in the entire sample. Using the ICIQ definition of UI based on questions 3, 4, and 5 of the tool, there was a slightly higher rate of incontinence of $47.4 \%$ in the same population. Also, according to ICIQ-SF definitions, mild incontinence was much more common than moderate to severe UI (mild: $27.1 \%$, moderate: $14.8 \%$, severe: $5.5 \%$ ). Similar results for mild UI were found by Bedretdinova et al. $^{28}$ 
Table 3. The results of logistic regression analysis for UI (ICIQ-SF score $\geq 1$ ), urgency, stress and mixed type UI

\begin{tabular}{|c|c|c|c|c|c|c|c|c|c|}
\hline \multirow[t]{2}{*}{ Variables } & \multirow[t]{2}{*}{ Categories } & \multicolumn{2}{|c|}{ UI (ICIQ-SF score $\geq 1$ ) } & \multicolumn{2}{|c|}{$\begin{array}{l}\text { Urgency urinary } \\
\text { incontinence (UUI) }\end{array}$} & \multicolumn{2}{|c|}{$\begin{array}{c}\text { Stress urinary incontinence } \\
\text { (SUI) }\end{array}$} & \multicolumn{2}{|c|}{ Mixed type } \\
\hline & & $p$ value & OR $(C I 95 \%)$ & $p$ value & $O R(C I 95 \%)$ & $p$ value & OR $(C I 95 \%)$ & $p$ value & OR $(C I 95 \%)$ \\
\hline \multicolumn{2}{|c|}{ Nagelkerke $\mathrm{R}^{2}$} & 0.144 & & 0.074 & & 1.119 & & 1.129 & \\
\hline \multirow[t]{8}{*}{$\begin{array}{l}\text { Age } \\
\text { groups }\end{array}$} & $\begin{array}{l}25-29 \text { yrs } \\
\text { (ref. group) }\end{array}$ & & & & & & & & \\
\hline & $30-34$ yrs & $\mathrm{NS}$ & - & NS & & NS & & NS & \\
\hline & $35-39$ yrs & $\mathrm{NS}$ & - & NS & & 0.004 & $2.38(1.32-4.30)$ & NS & \\
\hline & $40-44$ yrs & 0.006 & $2.05(1.22-3.42)$ & $\mathrm{NS}$ & & $<0.001$ & $3.42(1.89-6.21)$ & 0.011 & $5.03(1.42-17.59)$ \\
\hline & $45-49$ yrs & 0.003 & $2.21(1.31-3.73)$ & $\mathrm{NS}$ & & $<0.001$ & $3.66(2.01-6.69)$ & 0.004 & $6.40(1.84-22.37)$ \\
\hline & $50-54$ yrs & 0.000 & $3.13(1.83-5.36)$ & NS & & $<0.001$ & $3.82(2.08-7.03)$ & 0.018 & $4.60(1.30-16.36)$ \\
\hline & $55-59$ yrs & 0.001 & $2.52(1.46-4.34)$ & NS & & $<0.001$ & $4.02(2.17-7.45)$ & 0.008 & $5.58(1.58-19.76)$ \\
\hline & $60-64$ yrs & 0.001 & $2.90(1.59-5.28)$ & 0.013 & $2.54(1.22-5.30)$ & $<0.001$ & $3.29(1.70-6.38)$ & $<0.001$ & $5.53(1.63-4.74)$ \\
\hline \multirow[t]{2}{*}{ Education } & $\begin{array}{l}\text { More than } 8 \text { years } \\
\text { (ref. group) }\end{array}$ & & & & & & & & \\
\hline & Less than 8 years & 0.001 & $1.67(1.25-2.25)$ & 0.005 & $1.75(1.18-2.59)$ & 0.003 & $1.60(1.17-2.19)$ & $<0.001$ & $2.78(1.63-4.74)$ \\
\hline \multirow{3}{*}{$\begin{array}{l}\text { Vaginal } \\
\text { birth }\end{array}$} & No (ref. group) & & & & & & & & \\
\hline & $1-2$ birth & $\mathrm{NS}$ & & NS & & NS & & $\overline{\mathrm{NS}}$ & \\
\hline & 3 and more birth & 0.005 & $1.79(1.20-2.68)$ & 0.017 & $1.34(1.12-3.11)$ & 0.003 & $1.88(1.23-2.85)$ & 0.004 & $\begin{array}{c}2.78 \\
(1.38-5.62)\end{array}$ \\
\hline Constant & & $<0.001$ & 0.194 & $<0.001$ & 0.088 & $<0.001$ & 0.120 & $<0.001$ & 0.04 \\
\hline
\end{tabular}

Enter method, Logistic Regression. CI: Confidence interval; NS: Not significant.

Independent variables: Age group, marital and educational status, employment status, and birth types 
The age group in which the prevalence peak for UI is found differs decidedly between studies. In one of two different studies conducted in Canada, $28.8 \%$ of women over the age of 18 reported UI, while another study found that the prevalence of UI was higher $(51 \%)$ in women aged 45 and over. ${ }^{29-30}$

In this study, women over the age of 45 had twice as much urinary incontinence as younger women.

Women in the west of Turkey are reported to have more UI than those living in the East, while other research has shown the opposite. ${ }^{26-27}$

Thus, previous reports have presented conflicting geographical findings. In our study, there was no statistically significant difference between regions. This difference between our study and the others may be related to the selected population and the applied method. In addition, there was a statistically significant difference among women with $<8$ years of education compared to women with more years of education. Similarly, a significant increase in UI prevalence was found in women with a history of more than three vaginal births, compared to those who did not give birth or had fewer vaginal births. Koçak et al. reported that the number of births was a designated risk factor for UI. However, their results did not support the relationship between urinary incontinence and mode of delivery. ${ }^{2}$ Demir et al. reported that women with stress UI gave birth more often and that multiparity was an independent risk factor for stress UI. They found that the level of education was highly associated with hygiene and urinary tract infections that lead to UI in women. But in a multivariate analysis, a reduced level of education was found only as an independent risk factor for stress. They stated that this may be related to the higher parity numbers of the participants with lower education levels in their studies. ${ }^{18}$ According to the Turkey Demographic and Health Survey 2018, which is held every 5 years across Turkey, the total fertility rate in women was found to be 4.2 in the "uneducated or unable to complete primary school" group, while it was 1.8 in those with "high school and above" education. ${ }^{31}$

Karmakar et al. Using the Patient Global Impression of Improvement (PGI-I) with reasonable specificity (85\%) and sensitivity $(90 \%)$, determined a postoperative ICIQ-SF score cut-off of $\leq 6$ as a predictor of a successful outcome. ${ }^{31}$ In our sample, $20.3 \%$ of women with incontinence ICQ-SF score was $>6$.

The main limitations of this study are that the educational decency of the women involved in the study is higher than in Turkey, and some questions about UI are not placed in the survey to avoid extending the duration of the survey.
On the other hand, as far as we know, this study is one of the main national studies in Turkey, where the prevalence of female UI is investigated using standard epidemiological sampling methods. Because it is a stratified randomization method among female individuals enrolled in family physician lists, the results are therefore likely to represent a true national prevalence of female UI in the 25-64-year-old female population.

\section{CONCLUSION}

In Turkish women, urinary incontinence is a common health issue. The ICIQ-SF appears to be an appropriate and useful tool for determining national prevalence in a representative sample. However, clinicians should be aware that the ICIQ-SF is not a disease, but rather a symptom of urinary incontinence. These findings indicate that being over 45 years old, having a low education level, and having more than three vaginal deliveries are important risk factors for UI, whereas geographic location has no effect on the prevalence of UI in Turkey. The high rate of urinary incontinence in this population emphasizes the importance of increasing the knowledge and experience of primary care physicians. In family health units, UI screening can be used as a preventive health measure by using the ICQ-SF. As a result, we recommend that the ICIQSF query form be included as a screening tool for the detection of urinary incontinence in adult women in national preventive women's health programs.

\section{Special Thanks}

We would like to thank the esteemed family physicians, whose names are written below, for their assistance in the data collection process of the study: Ayşegül Kabanlı, Ayşen Mert Bengi, Sibel Baktır Altuntaş, Kürşat Özkök, Ömer Erdoğan, Saide Eda Cebeci, Gülçin Özkan Onur, Serpil İnan, Hüseyin Güntürkün, Arda Nermin Sümer, Şenay Koçakoğlu, Sema Aypolat Kurtuluş, İlker Boler, Şevket Akar, Fikri Ozan Arslan, Mehmet Ünlüsoy, Murat Tolga, Hülya Görgün, Yıldıray Demirci, Olgun Göktaş, Nihan Zonüzi, Handan Karahan Saper, Senem Aslan, Pınar Bilgili, Ekin Saba, Orhan Tekin, Hakan Şen, Kasım Ünalan, Cem Bilgiç, Bilge Sönmez, Kerim Güner Tüzün, Şehnaz Hatipoğlu.

* We declare that there is no conflict of interest related to this research.

* The summary of this study was presented as an oral presentation at the 5th National Congress of Functional Urology and Women's Urology held in Antalya on October 5-8, 2017. 


\section{REFERENCES}

1. Hunskaar S, Arnold EP, Burgio K, Diokno AC, Herzog AR, Mallett VT. Epidemiology and natural history of urinary incontinence. Int Urogynecol J Pelvic Floor Dysfunct. 2000;11(5):301-19.

2. Kocak I, Okyay P, Dundar M, Erol H, Beser E. Female urinary incontinence in the west of Turkey: prevalence, risk factors and impact on quality of life. Eur Urol 2005;48(4):634-41.

3. Dursun P, Dogan NU, Kolusari A, Dogan S, Ugur MG, Komurcu O, et al. Differences in geographical distribution and risk factors for urinary incontinence in Turkey: analysis of 6,473 women. Urol Int. 2014;92(2):209-14.

4. Address Based Population Registration System Results. Ankara: TurkStat, 2018. [Cited 2018 Nov. 1] Available from:https://biruni.tuik.gov.tr/DIESS/Siniflama SurumListeAction.do?turId=7\&turAdi=\%205. $\% 20$ Geographical\%20Classifications\&guncel= $\mathrm{Y}$

5. Urbaniak, G, C., Plous, S. Research Randomizer (Ver.4.0) [Computer software] [Cited 2018 Nov. 1] Available from: http://www.randomizer.org.

6. Cetinel B, Ozkan B, Can G. The validation study of ICIQ-SF Turkish version. Turk J Urol 2004;30(3):332-8.

7. Klovning A, Avery K, Sandvik H, Hunskaar S. Comparison of two questionnaires for assesing the severity of urinary incontinence: The ICIQUI SF versus the incontinence severity index. Neurourol Urodyn 2009;28(5):411-5.

8. Minassian VA, Drutz HP, Al-Badr A. Urinary incontinence as a worldwide problem. Int $\mathrm{J}$ Gynecol Obstet 2003;82(3):327-38.

9. Cerruto MA, D'Elia C, Aloisi A, Fabrello M, Artibani W. Prevalence, incidence and obstetric factors' impact on female urinary incontinence in Europe: a systematic review. Urol Int 2013;90(1):1-9.

10. Irwin DE, et al. Population-based survey of urinary incontinence, overactive bladder, and other lower urinary tract symptoms in five countries: results of EPIC Study. Eur Urol 2006;50(6):1306-15.

11. Minassian VA, Stewart WF, Wood GC. Urinary incontinence in women. Obstet Gynecol 2008;111(2 Pt 1):324-31.

12. Ebbesen MH, Hunskaar S, Rortveit G, Hannestad YS. Prevalence, incidence and remission of urinary incontinence in women: longitudinal data from the Norwegian HUNT study (EPINCONT). An important epidemiological study of the natural history of incontinence in women. BMC Urol 2013;13: 27.
13. Zhang L, Zhu L, Xu T, Lang J, Li Z, Gong J, et al. A population-based survey of the prevalence, potential risk factors, and symptom-specific bother of lower urinary tract symptoms in adult Chinese women. Eur Urol 2015;68(1):97-112.

14. Taylor DW, Weir M, Cahill JJ, Rizk DEE. The self-reported prevalence and knowledge of urinary incontinence and barries to Health Careseeking in a community sample of Canadian Women. Am J M Sc 2013;3(5):97-102.

15. Milliard R. The prevalence of urinary incontinence in Australia. Aust Continence J. 1998;4:92-9.

16. Turan C, Zorlu CG, Ekin M, Hancerliogullari N, Saracoglu F. Urinary incontinence in women of reproductive age. Gynecol Obstet Invest 1996;41(2): 132-4.

17. Özdemir K, Şahin S, Özerdoğan N, Ünsal A. Evaluation of urinary incontinence and quality of life in married women aged between 20 and 49 years (Sakarya, Turkey). Turk J Med Sci 2018;48(1):100-9.

18. Demir Ö, Sen V, Irer B, Bozkurt O, Esen A. Prevalence and Possible Risk Factors for Urinary Incontinence: A Cohort Study in the City of Izmir. Urol Int 2017;99(1):84-90.

19. Güvenç G, Kocaöz S, Kök G. Quality of life in climacteric Turkish women with urinary incontinence. Int. J Nurs Pract 2016;22(6):64959.

20. Cayan S, Yaman O, Orhan I, Usta M, Başar M, Resim S, et al. Prevalence of sexual dysfunction and urinary incontinence and associated risk factors in Turkish women. Eur J Obstet Gynecol 2016;203:303-8.

21. Akkus Y, Pinar G. Evaluation of the prevalence, type, severity, and risk factors of urinary incontinence and its impact on quality of life among women in Turkey. Int Urogynecol J 2016;27(6):887-93.

22. Gözükara F, Koruk I, Kara B. Urinary incontinence among women registered with a family health center in the Southeastern Anatolia Region and the factors affecting its prevalence. Turk J Med Sci 2015;45(4):931-9.

23. Kaşıkçı M, Kılıç D, Avşar G, Şirin M. Prevalence of urinary incontinence in older Turkish women, risk factors, and effect on activities of daily living. Arch Gerontol Geriatr 2015;61(2):217-23.

24. Baykus N, Yenal K. Prevalence of urinary incontinence in women aged 18 and over and affecting factors J Women Aging 2020;32(5):578-90.

25. Özcan F, Özkürkçügil C, Etiler N. Frequency of urinary incontinence in women admitted to a family health center. Turkish Journal Of Family Medicine 2016;20(1): 15-20

26. Zumrutbas AE, Bozkurt AI, Tas E, Acar C I, Alkis O, Coban K, et al. Prevalence of lower 
urinary tract symptoms, overactive bladder and urinary incontinence in western Turkey: Results of a population-based survey. Int $\mathrm{J}$ Urol 2014;21(10):1027-33.

27. Onur R, Deveci SE, Rahman S, Sevindik F, Acik Y. Prevalence and risk factors of female urinary incontinence in eastern Turkey. Int $\mathrm{J}$ Urol 2009;16(6):566-69.

28. Bedretdinova D, Fritel X, Panjo H, Ringa V. Prevalence of Female Urinary incontinence in the General Population According to Different Definitions and Study Designs. Eur Urol 2016;69(2):256-64.

29. Swanson JG, Kaczorowski J, Skelly J, Finkelstein M. Urinary incontinence: common problem among women over 45. Can Fam Physician 2005;51(1): 84-85.
30. Herschorn S, Gajewski J, Schulz J, Corcos J. A population-based study of urinary symptoms and incontinence: The Canadian Urinary Bladder Survey. BJU Int 2008;101(1):52-8.

31. Hacettepe University Institute of Population Studies. 2018 Turkey Demographic and Health Survey. Hacettepe University Institute of Population Studies, T.R. Presidency of Turkey Directorate of Strategy and Budget and TÜBİTAK, Ankara, Turkey.2019. p.61.

32. Karmakar D, Mostafa A, Abdel-Fattah M. A new validated score for detecting patientreported success on postoperative ICIQ-SF: a novel two-stage analysis from two large RCT cohortss. Int Urogynecol J 2017;28(1):95-100. 